\title{
Perceptions and Expectations of Students towards the Role of Academic Advisors in Malaysian Public Universities
}

\author{
Nguyen Thuy Van, Hamdan Said, Faizah Mohamad Nor
}

\begin{abstract}
Academic advising is affected by the expectations and perceptions of students towards the role of academic advisors. This study examines Malaysian public university students' perception and expectation towards the role of academic advisors. In this study, students' expectations refer to students' assumptions regarding the role of academic advisors upon their tertiary education registration while students' perceptions refer to the students' assumptions six months after registration for tertiary education. A self-developed questionnaire measuring students' perception and expectation towards academic advisors through academic, personnel, social and career development, was used for this study. The questionnaire was validated and piloted on randomly selected 40 undergraduate students. The reliability of the questionnaire using the alpha Cronbach was .809. A simple random sampling was used to select a total of 400 students from two Malaysian public universities to participate in this study. Data analysis revealed that at the early stage of tertiary education, students have high expectations towards the role of academic advisors but after six months of living on campus their perception towards the role of academic advisors decreases. The study provides several justifications for the decreasing towards the role of academic advisors.
\end{abstract}

Index Terms: academic advising, students' expectations, Malaysian public universities, students' perceptions

\section{INTRODUCTION}

University administrators are constantly exploring better ways to support student success [1-2]. Examples of initiatives introduced to ensure that students get continuous assistance throughout their studies are leadership training programs for student leaders [3], service-learning for critical pedagogy of teaching [4-8], entrepreneurship programs [9], student exchange programs [10], and academic advising [11-12].

Academic advising can be defined as the intentional interactions between students and university academic representatives to support students' growth and success [12-16]. It functions to inform students about academic requirements, assist students in finding academic and educational resources, and familiarize students with tertiary education cultures [11-12]. In this advising service, academic advisors assist students to understand university policies and requirements, provide referrals to on campus

Revised Manuscript Received on September 22, 2019.

Nguyen Thuy Van, School of Education, Universiti Teknologi Malaysia, Johor Bahru, Malaysia.

Hamdan Said, School of Education, Universiti Teknologi Malaysia, Johor Bahru, Malaysia. Email: p-hamdan@utm.my

Faizah Mohamad Nor, Language Academy, Universiti Teknologi Malaysia, Johor Bahru, Malaysia.

academic support resources, listen attentively to students' concerns, and support students in course selection that will best serve the students' goals [14,17-18]. In rendering this advising service, academic advisors are tasked to assist students to deal with many tertiary education mazes including making effective and thoughtful decisions regarding their future, adjusting their life skills with the tertiary education requirements, and promoting academic skills and knowledge required to succeed [18-19].

Academic advising can also be considered a partnership between the academic advisors and students throughout the period the students spend completing their studies [20]. In this advising process, an academic advisor is an academic staff that students can trust as they move from high school or matriculation college to university.

There are many ways universities in developed and developing countries run the academic advising service [21]. In many developed countries, academic advising is performed by professionals, those who earned their tertiary education in the fields of counseling and student affairs [22]. In Malaysian higher education context, academic advising is an additional job of academic staff (often called lecturers) [23] where academic advising services are managed and handled by the students' respective faculties [11-12,17-18]. The educational background of these academic staff are not necessarily related to counseling and student affairs [17]. In many cases, upon their appointment as academic advisors, they are required to attend short courses on academic advising run by their own institutions to familiarize themselves with academic advising-related aspects. This practice invites many expectations from students regarding the role of academic advisors.

The literature indicates that many universities tend to establish academic advising services prior to knowing the needs of their students and their academic advisors about the academc advising service [15-16]. As a result, the academic advising process may be negatively affected by the perceptions and expectations of students and academic advisors [24]. For example, students who misunderstood the concept and functions of academic advising may not get the actual benefits from the advising process involvement [25].

The literature also reveals that students have their own expectations and understandings of academic advising [26]. For example, some students may have the expectation that their academic advisors will set educational goals for them. They may come on campus with the expectation that their academic advisors are going to decide what courses they should be taking. This expectation may emerge based

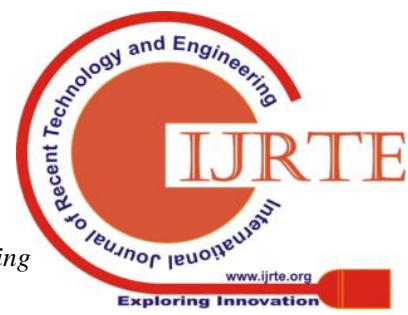


on their high school and matriculation college experience where decisions about courses to take are relatively fixed by the nature of the high school and matriculation college curriculum [18]). Students may not realize that tertiary level education posts them with a rich and diverse curriculum. Thus, they themselves, not their academic advisors, have to register the courses. Before making any decision, students may have to collect as much information as possible from appropriate resources.

Students may also have the expectations that their academic advisors will be meeting all their needs [27]. Students may not notice that making academic decisions at the university level education is a complex process. Thus, they may not notice that there is no guarantee that a single academic advisor can meet all their needs. Instead they may have to seek advice from many sources in addition to their academic advisors. These sources may include deans, department heads, and their programme coordinators.

Based on the above scenario, a study needs to be conducted to examine students' perceptions and expectations toward academic advising particularly about the role of academic advisor in academic advising. In this study, students' expectations refer to what the students hope that the academic advisors will do or provide for them while perception refers to what they actually encountered. This study argues that there is a high likely that the students' perceptions and expectations of the role of academic advisors would become more positive if they are satisfied with the advising process.

\section{METHODOLOGY}

This quantitative study employed a random sampling technique to select a total of 400 undergraduate students from two Malaysian public universities. Following a framework of [18], a self-developed questionnaire regarding the role of academic advisors was used to collect data. The role of academic advisor was measured through four dimensions: academic, personnel, social and career development. The questionnaire is divided into two sections: expectations and perceptions. 'Expectation' measures students' assumptions regarding the role of academic advisors upon registration of their tertiary education, while 'perception' measures students' assumption regarding the role of academic advisors six months after registration for tertiary education. The questionnaire comprises four aspects and used the following scale: 1=Strongly Disagree, 2=Disagree, 3=Agree, and $4=$ Strongly Agree. Prior to the actual data collection, the questionnaire was validated by three experts and then was pilot tested on randomly selected 40 undergraduate students from one public university in Malaysia. Using internal consistency approach for measuring reliability of the instrument, the alpha coefficient for the instrument is 0.809 , suggesting that the questionnaire has relatively high internal consistency [28].

\section{RESULTS}

Overall, data analysis revealed that students have high expectation $(m=3.08)$ towards the role of academic advisors in all the four aspects of development. However, along their studies and while undergoing their advising process with their academic advisors, their expectations dropped to a moderate level $(m=2.87)$. To be more specific, prior to their tertiary education, students have high expectations towards the role of academic advisors in the aspects of academic development $(m=3.0)$, personal development $(m=3.0)$, social skills development $(\mathrm{m}=3.01)$, and career development $(m=3.19)$. However, once they understand the need of the university education and they are part of the university system, their perceptions towards their academic advisors dropped to a moderate level in each of those four aspects as stated in Table 1.

\section{DISCUSSION AND CONCLUSION}

The findings revealed that at the early stage of their journey at tertiary education, students placed high expectations towards academic advisors in performing their roles in all four dimensions of development outcomes: academic development, personal development, social skills development, and career development. However, once they are on campus and experiencing the reality of tertiary education, become part of the university education system, and understood the requirements of university education, their expectations dropped in each of those four development outcomes. For example, in the academic development dimension, at the beginning of their studies, students strongly expect that their academic advisors monitor their academic progress and initiate clear discussion based on their strengths and interests to ensure that they can make accurate course selection. Once they understand what tertiary education entails and the need for them to shoulder some of academic-related matters, they place moderate expectations on the role of academic advisors in the aspect of academic development. The same situation is also observed with the three other aspects of development outcomes.

The finding is consistent with the studies of [29] and [26] which indicated that students may perceive their academic advising process less effective if after several months they have unsatisfactory experience with their academic advisors. The students seem to be aware of the important role played by the academic advisors, however after several months being on campus their expectations towards the roles of academic advisors changed. Their level of expectation towards the role of academic advisors dropped from that of the initial period of their university education. After several months of encouraging students to assume responsibility for their education, guiding the students to make effective and thoughtful decisions, and cultivating students' academic skills and knowledge needed to succeed [19], the students' expectations toward their academic advisors changed drastically. The presence of positive attitudes and willingness of the academic advisors to discuss academic matters pertaining to students' learning, including educating students about time management and teaching students' decision-making skills, enhances student academic achievement [30-32].

The finding of this study indicated that at the early stage of their tertiary education, students have high expectations towards their academic advisors to provide them with the information related to their own interest and career 
development, and to set goals for them. These expectations may have resulted from their high school or matriculation college experiences where guidance counsellors worked with them until they graduated. At this stage of education, the students' goals were clear to them and those goals have been achieved [18]. However, the model of successful matriculation college and high school guidance counselling are not in tandem with the university education where students have more career options and freedom to choose any career that matches their interests. Thus, the students are interested in discussing with their academic advisors about career development and career-related issues [21].

Table 1: Students' perceptions and expectations towards the role of academic advisor

\begin{tabular}{|c|c|c|c|c|c|}
\hline \multirow{3}{*}{ No. } & \multirow{3}{*}{$\begin{array}{l}\text { Items } \\
\text { I understand that the role of } \\
\text { academic advisor is to }\end{array}$} & \multicolumn{4}{|c|}{ STUDENTS $(n=400)$} \\
\hline & & \multicolumn{2}{|c|}{ Perception } & \multicolumn{2}{|c|}{ Expectation } \\
\hline & & Mean & $\mathrm{SD}$ & Mean & $\mathrm{SD}$ \\
\hline & $\begin{array}{c}\text { ACADEMIC } \\
\text { DEVELOPMENT }\end{array}$ & 2.95 & $\begin{array}{c}0.8 \\
7\end{array}$ & 3.14 & 0.85 \\
\hline 1 & $\begin{array}{l}\text { Monitor students' academic } \\
\text { progress. }\end{array}$ & 3.38 & $\begin{array}{c}0.6 \\
9\end{array}$ & 3.57 & 0.63 \\
\hline 2 & $\begin{array}{l}\text { Discuss with students about their } \\
\text { abilities and interests to master } \\
\text { course selection. }\end{array}$ & 2.93 & $\begin{array}{c}0.7 \\
1\end{array}$ & 3.11 & 0.81 \\
\hline 3 & $\begin{array}{l}\text { Introduce students to on campus } \\
\text { academic resources (e.g. } \\
\text { tutoring, etc.) }\end{array}$ & 2.93 & 0.9 & 2.95 & 0.93 \\
\hline 4 & $\begin{array}{l}\text { Explain to students on how } \\
\text { academic-related matters work } \\
\text { (timelines, policies, etc.) }\end{array}$ & 2.63 & $\begin{array}{c}1.0 \\
1\end{array}$ & 2.91 & 0.98 \\
\hline \multirow[t]{2}{*}{5} & $\begin{array}{l}\text { Provide students information on } \\
\text { degree requirements. }\end{array}$ & 2.9 & $\begin{array}{c}1.0 \\
4\end{array}$ & 3.16 & 0.91 \\
\hline & PERSONAL DEVELOPMENT & 2.9 & 1.0 & 3.0 & 0.9 \\
\hline 6 & $\begin{array}{l}\text { Encourage students to assume } \\
\text { responsibility. }\end{array}$ & 2.92 & $\begin{array}{c}1.0 \\
4\end{array}$ & 3.02 & 0.95 \\
\hline 7 & $\begin{array}{l}\text { Educate students ways to solve } \\
\text { their problems. }\end{array}$ & 2.96 & $\begin{array}{c}0.9 \\
2\end{array}$ & 3.01 & 0.97 \\
\hline 8 & $\begin{array}{l}\text { Teach students decision-making } \\
\text { skills. }\end{array}$ & 2.75 & $\begin{array}{c}1.0 \\
3\end{array}$ & 3.04 & 0.96 \\
\hline \multirow[t]{2}{*}{9} & $\begin{array}{l}\text { Educate students about time } \\
\text { management. }\end{array}$ & 2.9 & $\begin{array}{c}0.9 \\
5\end{array}$ & 2.96 & 0.91 \\
\hline & $\begin{array}{c}\text { SOCAL SKILL } \\
\text { DEVELOPMENT }\end{array}$ & 2.83 & $\begin{array}{c}0.9 \\
9 \\
\end{array}$ & 3.01 & 0.89 \\
\hline 10 & $\begin{array}{l}\text { Introduce students to on campus } \\
\text { non-academic resources (e.g. } \\
\text { counselling centre, sports centre, } \\
\text { etc.) }\end{array}$ & 2.83 & $\begin{array}{c}0.9 \\
8\end{array}$ & 3 & 0.85 \\
\hline 11 & $\begin{array}{l}\text { Develop students' } \\
\text { communication skills. }\end{array}$ & 2.79 & $\begin{array}{c}1.0 \\
2\end{array}$ & 3 & 1 \\
\hline \multirow[t]{2}{*}{12} & $\begin{array}{l}\text { Assist students in choosing } \\
\text { out-of-class activities (part-time } \\
\text { employment, exchange program, } \\
\text { etc.) }\end{array}$ & 2.86 & $\begin{array}{c}0.9 \\
7\end{array}$ & 3.02 & 0.83 \\
\hline & CAREER DEVELOPMENT & 2.73 & $\begin{array}{c}0.8 \\
8 \\
\end{array}$ & 3.19 & 0.88 \\
\hline 13 & $\begin{array}{l}\text { Develop educational career plan } \\
\text { with students }\end{array}$ & 2.94 & $\begin{array}{c}0.9 \\
4\end{array}$ & 3.13 & 0.88 \\
\hline \multirow[t]{2}{*}{14} & Career ready discussion & 2.51 & $\begin{array}{c}0.8 \\
1\end{array}$ & 3.25 & 0.88 \\
\hline & Average Mean & \multicolumn{2}{|c|}{ Moderate } & \multicolumn{2}{|c|}{ High } \\
\hline
\end{tabular}

The finding of this study indicated that the academic advisors should adapt themselves to changes. During the first few months of tertiary education, academic advisors are expected to assist their students to set career and life goals, to introduce students to on-campus non-academic resources, to develop students' communication skills, and to assist students in choosing out-of-class activities to ensure that students are able to build self-insight and esteem, and establish meaningful interpersonal relationships. [33] indicated that academic advisors need to enhance their students critical thinking and reasoning skills, and to clarify personal values and lifestyles. All these actions can change the perceptions of students who associated academic advising with negative image, lack of support, limited resources and rewards, and lack of priority for quality enhancement.

Several reasons may contribute to this negative perception. First, academic advisors in Malaysian public universities are academic staff or lecturers. They are overloaded with work in teaching, research, and publication. They may invest less time on academic advising and thus may have limited knowledge on academic advising [23,34]. Second, students may believe that they should manage their own studies independently and do not need to see their academic advisors frequently. They may think that only weak and at-risk students need to see their academic advisors on a regular basis [21]. They may also have a belief that they can find help through other resources outside of academic advising [19].

In conclusion, this study revealed that academic advising is a systematic process in which the academic advisor and the student enter a close dynamic relationship respectful the student's concerns and intended to aid the student in achieving educational, career, and personal goals through the use of institutional and community resources. In other words, academic advising is the process of helping students match their needs and goals. It is the process that also encourages students to think critically and develop actions to secure success in tertiary education. Students may not realize that tertiary level education posts them with a rich and diverse curriculum. Thus, decisions about what courses to take must be made by them, not their academic advisors. Before making any decision, students may have to collect as much information as possible from appropriate resources. In this regard, academic advisors frequently render help in defining what areas of interest the students want to pursue and to avoid. In the end, the students have to make up their minds regarding the content and direction of their education.

\section{ACKNOWLEDGMENT}

This study is sponsored by Ministry of Higher Education (MOHE) and Universiti Teknologi Malaysia with the FRGS Vote No.4F378.

\section{REFERENCES}

1. M. Dadgar, T. Nodine, K. R. Bracco, and A. Venezia, Integrating Student Supports and Academic. San Francisco, CA: West End, 2014.

2. W. R. Habley, and R. McClanahan, What Works in Student Retention? All Survey Colleges. Iowa City, IA: ACT, 2004.

3. H. Said, C. L. A. Pemberton, and I. Ahmad, "Effectiveness of leadership training programs in public universities of Malaysia in developing students' knowledge of leadership", World Applied Sciences Journal, vol $28(1)$, pp. 1-8, 2013.

4. H. Said, I. Ahmad, Z. Hassan, and Z. Awang, "Service-learning as critical pedagogy: Implications for students community awareness and citizenship development", Mediterranean Journal of Social Sciences, vol 6(2), pp. 471-478, 2015

5. I. Ahmad, and H. Said, "Application of Astin's theory of students' involvement in service-learning at higher education", Man in India, vol 96(1-2), pp. 231-245, 2016. 
6. I. Ahmad, H. Said, M. J. M. Janan, S. Sholihan, "Assessment of service-learning in higher education: Challenges and possibilities", Man in India, vol 96(6), pp. 1623-1633, 2016.

7. I. Ahmad, H Said, S. S. S. Mansor, M. Mokhtar, and F. A. Ghani, "Role of reflection in moderating the relationship between service-learning and civic development", Review of European Studies, vol 6(3), pp. 74-80, 2014.

8. H. Said, I. Ahmad, S. S. S. Mansor, and Z. Awang, "Exploring different perspectives on limitations and promises of service-learning as an innovative pedagogy: Review of literature", Mediterranean Journal of Social Sciences, vol 6(4S1), pp. 311-317, 2105

9. H. Said, I. Ahmad, M. A. M. Yusof, \& A. Jusoh, "Assessing the role of higher education in developing social entrepreneurship in Malaysia: A review of literature", Mediterranean Journal of Social Sciences, vol 6(2), pp. $583-587,2015$

10. H. Said, I. Ahmad, M. S. Mustaffa, and F. A. Ghani, "Role of campus leadership in managing change and challenges of internationalization of higher education.”, Mediterranean Journal of Social Sciences, vol 6(4S1), pp. 82-88, 2015

11. N. T. Van, H. Said, M. R. M. Rameli, N. A. Karim, N. Tajuddin, and T. T. Chai, "Role of academic advising in mitigating the challenges of ethnic minority students at Universiti Teknologi Malaysia", International Education Studies, vol 8(13), pp. 52-59, 2015.

12. N. T. Van, H. Said, Z. Awang, and A. Khan, "Student perspective on learning and development outcomes of academic advising at Universit Teknologi Malaysia", Man in India, vol 96(1-2), pp. 675-688, 2016.

13. Y. He, and B. L. Hutson, "Appreciative assessment in academic advising", The Review of Higher Education, vol 39(2), pp. 213-240, 2016.

14. N. T. Van, H. Said, A. Khan, and F. A. Ghani, "Academic advising models and practices of two Asian universities", Man in India, vol 97(19), pp 33-41, 2017.

15. J. S. Smith, "First-year student perceptions of academic advisement: A qualitative study and reality check", NACADA Journal, vol 22(2), pp 39-49, 2002.

16. C. L. Smith, and J. M. Allen, "Essential functions of academic advising: What students want and get", NACADA Journal, vol 26(1), pp. 56-66, 2006.

17. N. T. Van, H. Said, and A. Khan, "Components of an academic advising program standard for Malaysian public universities", Man in India, vol 96(6), pp. 1691-1702, 2016.

18. N. T. Van, H. Said, M. R. Mohd Rameli, and A. Khan, "Item analysis for measuring student and academic advisor's perspective towards the function of academic advising in Malaysian public universities", International Journal of Engineering and Technology (UAE), vol 7(3.30 Special Issue 30), pp. 269-273, 2018.

19. J. K. Drake, "The role of academic advising in student retention and persistence" About Campus, vol 16(3), pp. 8-12, 2011.

20. W. K. Paul, and C. Fitzpatrick, "Advising as servant leadership: Investigating student satisfaction", NACADA Journal, vol 35(2), pp. 28-35, 2015.

21. R. Y. S. Cheung, A. M. H. Siu, D. T. L. Shek, "Survey of needs and expectations for academic advising in a Hong Kong University", NACADA Journal, vol 37(2), pp. 21-31, 2017.

22. T. Christian, and J. Sprinkle, "College student perceptions and ideals of advising: An exploratory analysis", College Student Journal, vol 47(2), pp. 271-291, 2013

23. P. L. Tan, "What academic advisors need to provide better student support - lessons from a Malaysian medical school." Unpublished Thesis of Master of Philosophy, Stellenbosch University, South Africa, 2011.

24. Stepina, G. "Communicating the story of an academic advising program", Academic Advising Today, 30(2). Retrieved from https://www.nacada.ksu.edu/Resources/Academic-Advising-Today/ViewArticles/Communicating-the-Story-of-an-Academic-Advising-Program.as px, 2007.

25. Schreiner, L. A., "Increasing retention on a college campus through at-risk student identification and faculty student contact”. New Orleans: Paper presented at the Annual Meeting of the Southeastern Psychological Association. (ERIC Document Reproduction Service No. Ed 298 400), 1988

26. N. Saba"Ayon, "Academic advising: Perceptions of students in a Lebanese university”, IJAEDU-International E-Journal of Advances in Education vol 1(2), pp. 118-126, 2015.

27. M. Suvedi, R. P. Ghimire, K. F. Millenbah, and K. Shrestha, "Undergraduate students' perceptions of academic advising", NACTA Journal, vol 59(3), 227-233, 2015.

28. M. Tavakol, and R. Dennick, "Making sense of Cronbach's alpha", International Journal of Medical Education, vol 2, pp. 53-55, 2011.

29. R. Robbins, and K. M. Zarges, "Assessment of academic advising: A summary of the process". Retrieved March 2019 from NACADA Clearinghouse of Academic Advising Resources Web site

http://www.nacada.ksu.edu/Resources/Clearinghouse/View-Articles/Asse ssment-of-academic-advising.aspx, 2011

30. E. Harrison, "What constitutes good academic advising? Nursing students' perceptions of academic advising", Journal of Nursing Education, vol 48(7), pp. 361-366, 2009.

31. C. Nutt, "Assessing student learning in academic advising", Advising Today, vol 27, pp. 5-6, 2004.

32. A. D. Young-Jones, T. D. Burt, S. Dixon, and M. J. Hawthorne, "Academic advising: Does it really impact student success?", Quality Assurance in Education, vol 21(1), pp. 7-19, 2013.

33. D. G. Creamer, and E. G. Creamer, "Practicing developmental advising: Theoretical contexts and functional applications", NACADA Journal, vo 14(2), pp. 17-24, 1994.

34. W. R. Habley, Integrating academic advising and career planning. In R. B. Winston, T. K. Miller, S. C. Ender, T. J. Grites, \& Associates (Eds) Developmental Academic Advising (pp. 147-172). San Francisco: Jossey-Bass, 1984

\section{AUTHORS PROFILE}

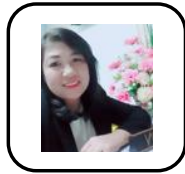

Nguyen Thuy Van has more than 10 years of working experiences in the field of teacher training and management of student development in Vietnamese university. During the 10 years of working, she published many articles in local Journals. She continued her study at $\mathrm{PhD}$ level at the Universiti Teknologi Malaysia and her thesis focuses on the academic advising development and implementation at public universities in Malaysia. Her PhD study on academic advising enables her to publish many indexed and non-indexed journal articles as well as conference papers Currently, she enjoys preparing multi-culture crossing environment for student development in higher education.

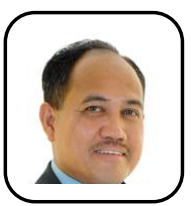

Dr Hamdan Said obtained his bachelor's degree of Science with Education from the Universiti Teknologi Malaysia (Malaysia), master's degree from the Queensland University of Technology (Australia), and doctoral degree from Idaho State University, USA majoring in Educational Leadership. He teaches undergraduate and postgraduate courses, and function as an active researcher, supervisor, an consultant. He conducted more than 30 research projects and currently leading two research projects under the Ministry of Education and members to four research projects. He is also a member of national level research project called Malaysian Soft Skills Scale (My3S). He supervises $\mathrm{PhD}$ and Master students in the area of higher education. He was invited as a keynote speaker for more than 30 international conferences oversea. He was appointed as a visiting professor to the University of Muslim Indonesia (2014), University of Sawerigading Makassar Indonesia (2014), University of Riau Indonesia (2015), dan Prima University of Indonesia (2015), and State University of Malang Indonesia (2016). He has published more than 70 journal articles. He also a board member to three international journals. He is also one of the auditors for Malaysian Quality Assurance (MQA) and has been an international auditor to Bangladesh higher education since 2016.

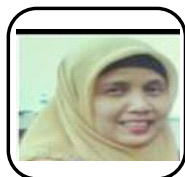

Associate Professor Faizah Mohamad Nor graduated from University of Malaya with a Bachelor's degree in Mathematics. She later pursued a Diploma in Education (T.E.S.L/ Math) from University of Malaya, M. Sc (T.E.S.P.) from Aston University (U.K.) and a $\mathrm{PhD}$ in T.E.S.L. (Universiti Teknologi Malaysia). Her publications are mainly in the area of Education and second language teaching and learning. She has co-authored 2 books 'English for Career Search' and 'English for Professional Communication', edited 5 books including 3 books on language learning, and published more than 50 book chapters, journal articles and conference proceedings. She has headed several national and university-leve research projects that investigated effective English language teaching practices in Malaysia, researched on the aspect of motivation to read in English among Malaysian learners, the use of English Language at the workplace among professionals in Malaysian companies, and the aspect of learner autonomy in English language learning. The study on 'English for Air Traffic Controllers: An Ethnographic Study of the Target Discourse Community', conducted with her research team won the Merit Award in the Congress of Science and Technology. Associate Professor Dr Faizah sits in the editorial board of 4 journals and is also an academic consultant for an academic programme offered by a higher learning institution in Malaysia.

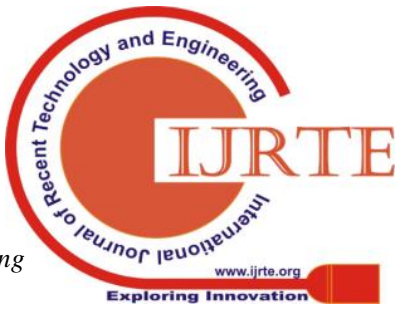

